\title{
Squaring the circle: academic and entertaining
}

Sometimes, less can be more. In ET's twenty years of publication, this issue has the smallest number of contributions ever listed: seven titles in all, whereas traditionally there have been ten or more. It also has the usual number of pages (sixty-four), which means that some or all of the articles are way beyond our longestablished norm. Yet at some point this had to happen.

It has always been part of its remit that English Today's 'articles' or 'papers' (or whatever one might call them) should be global and varied. If one is inclined to see ET as a magazine (and certainly it began life as a magazine) its contents are primarily articles (even features), but if it is a journal its contents are (or have become) papers. Or, some have been more article-like and some more paper-like as the years have passed. Yet, whatever it may be or have been, our content has belonged in the sub-traditions of both English liberal studies and 'liberal linguistics' (but not quite 'liberation linguistics').

Whatever the reality, as a publication ET is hard to pigeon-hole. However, there has been, throughout its twenty years, a slow shift from the more eclectic and humanistic towards the more academic and technical, yet entirely as a consequence of submissions received, not editorial intent. If there is an editorial policy (or even ideology), I hope it has been 'linguistic liberalism'.

ET has tended to be the creation of two kinds of people: regular readers who have also been contributors and (increasingly) scholars who are compellingly aware of what counts as a 'publication' in terms of prestige, promotion, and academic placement. The result has been a compromise in which a range of contributors worldwide has succeeded, variously and often ingeniously, in serving both the aims of linguistic ('Anglistic') scholarship in a general and generous sense and the needs and pressures of promotion and preferment in academic life.

As a consequence, "The international review of the English language' will keep trying to square this interesting circle. Thus, in the current issue we see various ways in which the interests and expectations of academe have blended with a wish that the presentation of research can be rhetorically resourceful (and even entertaining) while it meets to the full the conventions, necessities, and rigours of academic life.

Tom McArthur

The editorial policy of English Today is to provide a focus or forum for all sorts of news and opinion from around the world. The points of view of individual writers are as a consequence their own, and do not reflect the opinion of the editorial board. In addition, wherever feasible, ET generally leaves unchanged the orthography (normally British or American) and the usage of individual contributors, although the editorial style of the journal itself is that of Cambridge University Press. (c) Cambridge University Press 2005 No contents may be reproduced by any means without the permission of Cambridge University Press.

English Today (ISSN 0266-0784) is a quarterly.

Publisher: Cambridge University Press, The Edinburgh Building, Cambridge CB2 2RU, United Kingdom. Telephone (01223) 312393 Email:

journals_marketing@cup.cam.ac.uk

Subscriptions: The 2005 subscription price (excluding VAT) for four issues for libraries and institutions, which includes print and electronic access, is f93 outside of North America; $£ 32$ for individuals; $f 24$ for students and the retired. The electronic-only price available to institutional subscribers is f79. Prices include delivery by air where appropriate. Apply to Jane Crossland at the above address.

Advertising Sales: write to the Advertising Promoter at the above address.

USA, CANADA AND MEXICO:

Publisher: Cambridge University Press, 40 West 20th Street, New York, NY 10011-4211, USA.

Telephone (212) 9243900.

Subscriptions: The 2005 subscription price (excluding VAT) for four issues for libraries and institutions, which includes print and electronic access, is $\$ 147$ in USA, Canada and Mexico; \$50 for individuals; $\$ 37$ for students and the retired. The electronic-only price available to institutional subscribers is $\$ 120$. Apply to Marianne Headrick at the above address.

Advertising Sales: write to the Advertising Coordinator at the above address.

Periodicals postage paid at New York, NY and at additional mailing offices. POSTMASTER: send address changes in USA, Canada and Mexico to English Today, Cambridge University Press, 110 Midland Avenue, Port Chester, New York, NY 10573-4930, USA.

Japanese prices for institutions are available from Kinokuniya Company Ltd, P.O. Box 55, Chitose, Tokyo 156, Japan.

Contacting the Editor: Email Dr Tom McArthur at <Scotsway@aol.com> or write to him at 22-23 Ventress Farm Court, Cherry Hinton Road, Cambridge CB1 8HD, UK. Tel 01223245934.

Internet access This journal is included in the Cambridge Journals Online service which can be found at http://uk.cambridge.org/journals. For further information on other Press titles access http://uk.cambridge.org.

Designed and typeset by Peter Ducker. Printed in the United Kingdom at the University Press, Cambridge. 